\title{
Increased Rac1 Activation in the Enhanced Carbachol-Induced Bronchial Smooth Muscle Contraction of Repeatedly Antigen-Challenged Mice
}

\author{
Yuki Kai, ${ }^{a}$ Momoko Motegi, ${ }^{a}$ Yuta Suzuki, ${ }^{a}$ Yui Harada,${ }^{a}$ Hiroto Takeuchi, ${ }^{a}$ Risako Kon, ${ }^{a}$ \\ Nobutomo Ikarashi, ${ }^{a}$ Yoshihiko Chiba, ${ }^{b}$ Junzo Kamei, ${ }^{a}$ and Hiroyasu Sakai ${ }^{*}, a$ \\ ${ }^{a}$ Department of Biomolecular Pharmacology, School of Pharmacy, Hoshi University; 2-4-41 Ebara, Shinagawa- \\ ku, Tokyo 142-8501, Japan: and ${ }^{b}$ Department of Physiology and Molecular Sciences, School of Pharmacy, Hoshi \\ University; 2-4-41 Ebara, Shinagawa-ku, Tokyo 142-8501, Japan. \\ Received May 16, 2019; accepted June 14, 2019; advance publication released online June 25, 2019
}

Recently, we demonstrated that Rac1 upregulation is involved in augmented bronchial smooth muscle (BSM) contractions of antigen-challenged mice. However, change in G protein-coupled receptor (GPCR)induced Rac1 activation remains unknown in BSMs of repeatedly antigen-challenged (Chal.) mice. We here examined carbachol (CCh)-induced Rac1 activation in BSMs of Chal. mice. Gene expression levels of both Racl and Rac-guanine nucleotide exchange factors (GEFs), such as Tiam1 and Trio, were increased in BSMs of Chal. mice. Furthermore, CCh-induced Racl activation was inhibited by pretreatment with Rac1-GEF inhibitor NSC23766 and Rac1 inhibitor EHT1864 in BSMs of sensitized-control (S.C.) and Chal. mice. Compared with S.C. mice, CCh-induced Racl activation was increased in BSMs of Chal. mice. In conclusion, we reported that increased CCh-induced Racl activation via Tiam1 and Trio upregulation, in addition to upregulate Rac1, may be involved in increased CCh-induced BSM contractions in Chal. mice.

Key words bronchial smooth muscle; carbachol; asthma; Rac1; Rac-guanine nucleotide exchange factor (GEF)

\section{INTRODUCTION}

The Rho guanosine 5'-triphosphatase (GTPase) superfamily comprises 22 family involved Ras family of $G$ proteins. Rho GTPases, particularly Cdc42, Rac1, and RhoA, have been linked to a large number of cellular functions, including reorganization of the cytoskeleton, such as formations of the filopodia, lamellipodia, and stress fiber. ${ }^{1)}$ These GTPases cycle between a guanosine 5 '-diphosphate (GDP)-loaded "ON" and a GDP-loaded "OFF" state. ${ }^{1)}$ Regulators controlling these states include guanine nucleotide exchange factors (GEFs), GTPase activating proteins, and guanine nucleotide dissociation inhibitors. ${ }^{2)}$

Recently, we have demonstrated that Racl protein plays crucial role in G protein-coupled receptor (GPCR)-induced bronchial smooth muscle (BSM) contractions. ${ }^{3)}$ Further, we reported that Racl upregulation may be involved in augmented BSM contractions of repeatedly antigen-challenged (Chal.) mice. ${ }^{4)}$ Racl activation is mediated by various GEFs, including Tiaml and Trio. ${ }^{5-8)}$ However, change in GPCR-induced Racl activation in BSMs of Chal. mice remains unknown. We examined the gene expression of Rac1-GEFs (Tiam1 and Trio) and carbachol (CCh)-induced Racl activation in BSMs of Chal. mice.

\section{MATERIALS AND METHODS}

Animals Male BALB/c mice (7-8 weeks old) were purchased from the Tokyo Laboratory Animals Science Co., Ltd. (Tokyo, Japan) and housed in a pathogen-free facility. All animal experiments were approved by the Animal Care Committee of the Hoshi University, Tokyo, Japan (permission code: 30-091).

Sensitization and Antigenic Challenges Sensitization and antigenic challenges in mice models of allergic bronchial hyper-responsiveness were performed as described previously. ${ }^{9)}$ Control (sensitized-control, S.C.) groups of mice received the same immunization procedure but inhaled saline aerosol instead of ovalbumin (OA; Sigma-Aldrich, MO, U.S.A.) challenge.

Functional Studies The suspension of left bronchi in organ baths were performed as described previously. ${ }^{4)}$ Fifteen minutes after the last wash, $\mathrm{CCh}(10 \mu \mathrm{M})$ or $\mathrm{K}^{+}(60 \mathrm{mM})$ was applied. The BSM were treated with NSC23766 $(100 \mu \mathrm{M})$ or EHT1864 (10 $\mu \mathrm{M}$; Cayman Chemical, MI, U.S.A.) for $20 \mathrm{~min}$ before application of $\mathrm{CCh}$ or $\mathrm{K}^{+}$to evaluate the effect of Racl inhibitors on CCh-induced BSM contractions. Force development was observed in response to $\mathrm{K}^{+}$depolarization in the presence of atropine $(1 \mu \mathrm{M})$.

Rac1 Activity Pull-Down Assay Racl activation assays were performed using a commercially available Racl activation assay kit (Thermo Pierce \#16118), according to the manufacturer's protocol.

Quantitative (q)RT-PCR Analysis qRT-PCR was performed as described previously. ${ }^{4)}$ The following PCR primer sets were used: for Tiam1, 5'-CAA GGT CGCCAGTCACAT CA-3' and 5'-TCTCCCGTCTGCTCAGCAAT-3' were used to generate a $90 \mathrm{bp}$ PCR product; for Trio, 5'-CGGGATGCC ATC GAT ATC AT- 3 ' and 5'-TCC TCC GTA TCG AAG TCA TTC A-3' were used to generate an $83 \mathrm{bp}$ PCR product; for Racl, 5'-AGT TGC GTT GTGCTG AGA ACA-3' and 5'-CTCCAG AAGCTGCGG TCT TC-3' were used to generate an 80 bp PCR product; and for Gapdh, 5'-CCTCGTCCCGTA GACAAA ATG-3' and 5'-TCTCCACTT TGCCAC TGCAA-3' were used to generate a $100 \mathrm{bp}$ PCR product.

Immunoblotting Imunoblotting was performed as described previously. ${ }^{4}$ ) The polyvinylidene difluoride membranes were incubated with the following primary antibodies: rabbit 
A
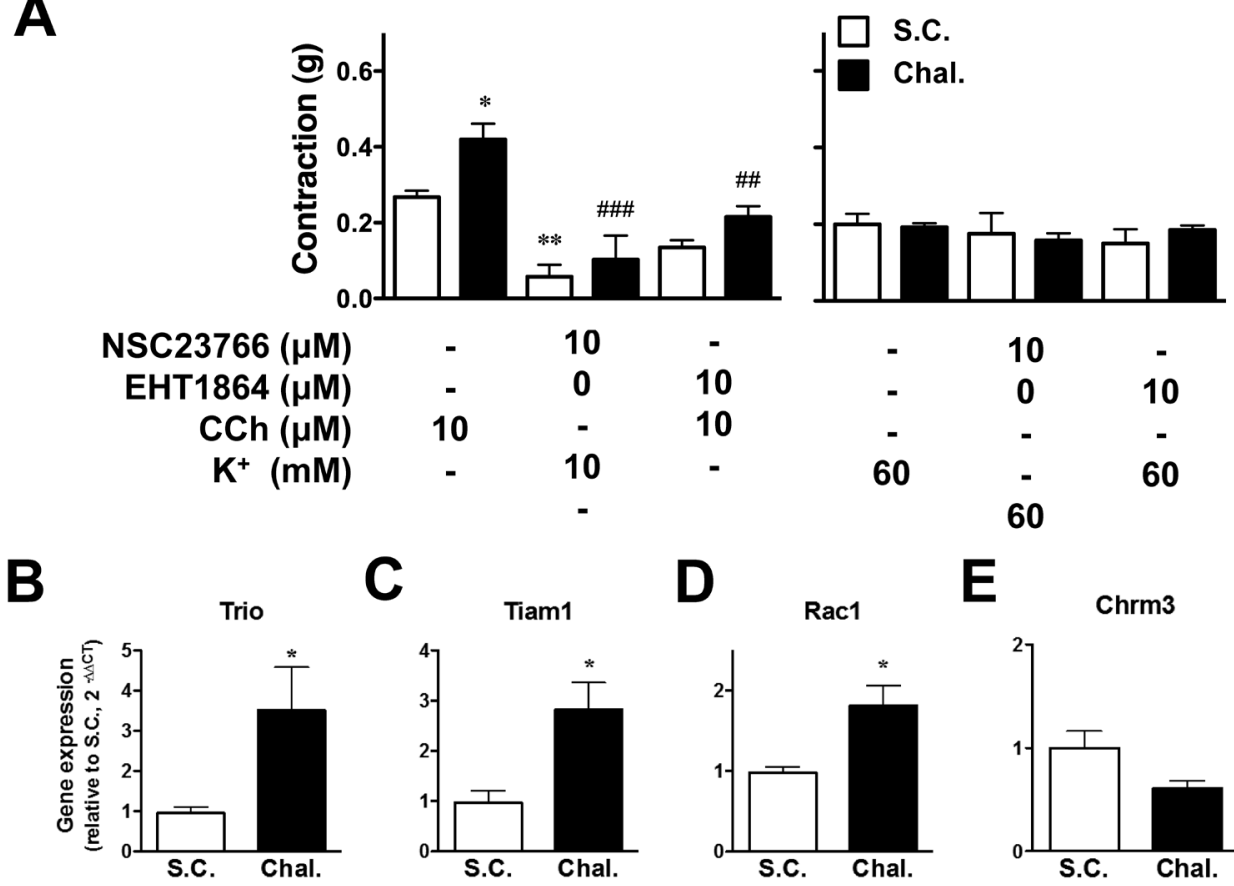

C

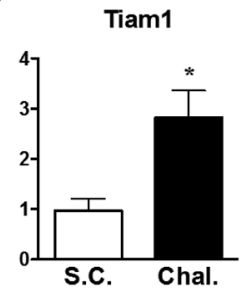

D

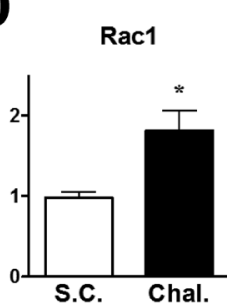

E

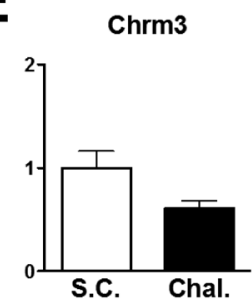

Fig. 1. Effects of NSC23766 and EHT1864 on Carbachol (CCh) and High $\mathrm{K}^{+}$Depolarization-Induced Contractions in the Bronchial Smooth Muscles (BSMs) of Sensitized-Control (S.C.) and OA-Challenged (Chal.) Mice

The $10 \mu \mathrm{M} \mathrm{CCh}$ and $60 \mathrm{mM}$ high $\mathrm{K}^{+}$responsiveness in the absence or presence of $100 \mu \mathrm{M} \mathrm{NSC23766} \mathrm{and} 10 \mu \mathrm{M}$ EHT1864 (A). Each column represents the mean \pm S.E.M. of $4-8$ independent experiments. ${ }^{*} p<0.05$ and ${ }^{* *} p<0.01 v s$. CCh only (S.C.). ${ }^{\# \#} p<0.01$ and ${ }^{\# \#} p<0.001 v s$. CCh only (Chal.). Gene expression changes of Trio, Tiam1, Racl, and Chrm 3 in BSMs of S.C. and Chal. mice (B-E). Each column represents the mean \pm S.E.M. from four experiments. ${ }^{*} p<0.05$ s. S.C.

A

$\mathbf{F}$

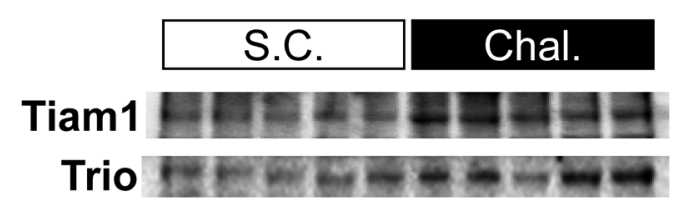

Rac1

Chrm3

GAPDH
B
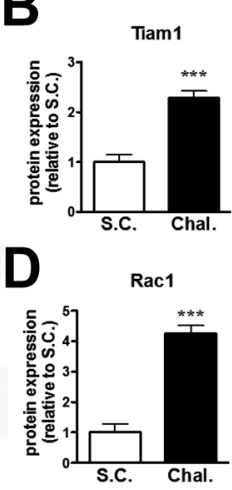

C

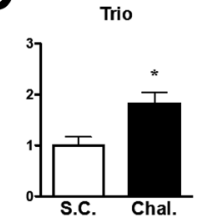

E

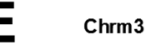

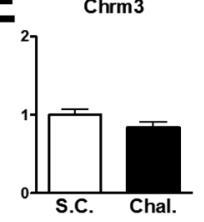

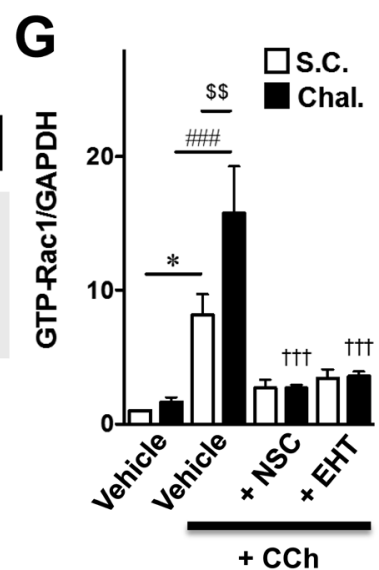

Fig. 2. Protein Levels of Tiam1, Trio, Rac1, and Chrm3 and CCh-Induced Rac1 Activation in BSMs of S.C. and Chal. Mice

Representative photographs showing bands for Tiam1, Trio, Racl, Chrm3, and Gapdh (A). Levels of Tiam1, Trio, Rac1, and Chrm3 expressed as the ratios of the intensities of Tiam1, Trio, Rac1, and Chrm 3 to Gapdh protein bands (B-E). Each column represents the mean \pm S.E.M. from four experiments. $* p<0.05$ and $* * * p<0.001 v s$. S.C. The active form of Racl, GTP-bound Racl, in BSMs of mice was measured using Racl pull-down assay (F and G). Representative photographs showing bands for pull-down Racl-GTP (upper) and Gapdh in total protein (lower). Each column represents the mean \pm S.E.M. of 3-4 independent experiments. * $p<0.05$ : Vehicle (S.C.) vs. CCh (S.C.). ${ }^{\# \# ~} p<0.001$ : Vehicle (Chal.) vs. CCh (Chal.). ${ }^{\$ \$} p<0.01$ : CCh (S.C.) vs. CCh (Chal.), ${ }^{\dagger \dagger} p<0.001$; CCh (Chal.) vs. NSC + CCh (Chal.) or EHT + CCh (Chal.). 
anti-Rac1 (1:1000; Merck Millipore, MA, U.S.A.), Tiam1 ( 1 : 1000; Bethyl Laboratories, Inc., TX, U.S.A.), Trio (1 : 1000; Aviva System Biology, CA, U.S.A.), Chrm3 (1:1000; Santa Cruz Biotechnology, Inc., TX, U.S.A.), and glyceraldehyde3-phosphate dehydrogenase (GAPDH) (1:5000; Cell Signaling Technology Japan, K.K., Tokyo, Japan).

Statistical Analysis Indicators of statistical significance were generated using GraphPad Prism 5 for Max OS X (GraphPad Software, Inc., CA, U.S.A.). Results are expressed as mean \pm standard error of the mean (S.E.M.). Statistical significance of difference was determined by unpaired Student's $t$-test or two-way ANOVA with post hoc Bonferroni or Newman-Keuls for differences among individual groups. $p<0.05$ was considered statistically significant.

\section{RESULTS AND DISCUSSION}

Previously, we have reported that muscarinic agonist CChinduced maximal contraction may be augmented by repeated OA challenges in BSMs of mice and found that $10 \mu \mathrm{M}$ CChinduced contraction was the maximum response in BSM contractions of mice. ${ }^{4)}$ We examined the effect of Racl inhibitors (NSC23766 and EHT1864) on $10 \mu \mathrm{M}$ CCh-induced BSM contraction in both S.C. and Chal. mice. Reportedly, Tiam1- or Trio-induced Racl activation is specifically inhibited by NSC23766; however, activation of other small G proteins, such as $\mathrm{Cdc} 42$ and Rho, remains unaffected even by $100 \mu \mathrm{M}$ NSC23766, ${ }^{10)}$ whereas Racl downstream signaling and guanine nucleotide displacement are selectively inhibited by EHT1864; however, activation of other small GTPase remain unaffected even by $50 \mu \mathrm{M}$ EHT1864. ${ }^{11)}$ Compared with S.C. mice, $10 \mu \mathrm{M}$ CCh-induced BSM contraction was increased in Chal. mice. This CCh-induced contraction was attenuated by pretreatment with $100 \mu \mathrm{M}$ NSC23766 or $10 \mu \mathrm{M}$ EHT1864; however, $60 \mathrm{mM}$ high $\mathrm{K}^{+}$depolarization-induced contraction was not different in both S.C. and Chal. mice. Moreover, the high $\mathrm{K}^{+}$-induced contraction was not inhibited by Racl inhibitors, NSC23766 and EHT1864 (Fig. 1A). These findings are consistent with those of our previous reports. ${ }^{3,4)}$ Recently, we have reported that Racl upregulation may be involved in augmented BSM contractions of Chal. mice. ${ }^{4)}$ As mentioned above, NSC23766 inhibited Rac1 binding and activation by the Rac1-specific GEFs, Trio or Tiam $1 .^{10)}$ The muscarinic acetylcholine receptor $\mathrm{M}_{3}(\mathrm{Chrm} 3)$ mediates contractile responses in the airway smooth muscle. ${ }^{12,13)}$ Therefore, we examined the gene expressions of Racl, Tiam1, Trio, and Chrm3 in BSMs of Chal mice. Interestingly, although the gene expression level of Chrm3 remained unchanged, that of Racl, Tiam1, and Trio was increased in BSMs of Chal mice (Figs. 1B-E). Further, we investigated the protein levels of Tiam1, Trio, Rac1, and Chrm3 in BSMs of S.C. and Chal. mice. In addition to gene expression changes, protein levels of Rac1, Tiam1, and Trio were increased in BSMs of Chal. mice (Figs. 2A-E). In summary, Racl upregulation as well as activation may be involved in augmented BSM contractions of Chal. mice. Therefore, we examined CCh-induced Racl activation in BSMs of Chal. mice. CCh induced Racl activation (Racl-GTP), and this CCh-induced Racl activation was inhibited by pretreatment with NSC23766 and EHT1864 in BSMs of S.C. and Chal. mice. Compared with S.C. mice, the CCh-induced Racl-GTP was increased in BSMs of Chal. mice and the activation of Racl was attenuated by NSC23766 and EHT1864 (Figs. 2F, $\mathrm{G})$. However, further research is needed to determine the detailed activations of Racl-GEFs, such as Tiam1 and Trio, by $\mathrm{CCh} / \mathrm{Chrm} 3$.

\section{CONCLUSION}

In conclusion, we reported that not only upregulated Rac1 but also CCh-induced Racl activation, via upregulation of Tiaml and Trio, may be involved in increased CCh-induced BSM contractions of Chal. mice. However, further studies on the Racl signaling are needed to examine new treatment targets in asthma.

Conflict of Interest The authors declare no conflict of interest.

\section{REFERENCES}

1) Jaffe AB, Hall A. Rho GTPases: biochemistry and biology. Annu. Rev. Cell Dev. Biol., 21, 247-269 (2005).

2) Etienne-Manneville S, Hall A. Rho GTPases in cell biology. $\mathrm{Na}$ ture, 420, 629-635 (2002).

3) Sakai H, Kai Y, Sato K, Ikebe M, Chiba Y. Racl modulates G-protein-coupled receptor-induced bronchial smooth muscle contraction. Eur. J. Pharmacol., 818, 74-83 (2018).

4) Kai Y, Motegi M, Suzuki Y, Takeuchi H, Harada Y, Sato F, Chiba Y, Kamei J, Sakai H. Up-regulation of Racl in the bronchial smooth muscle of murine experimental asthma. Basic Clin. Pharmacol. Toxicol., 125, 8-15 (2019).

5) Kowluru A. Small G proteins in islet beta-cell function. Endocr. Rev., 31, 52-78 (2010).

6) Sidarala V, Veluthakal R, Syeda K, Kowluru A. EHT 1864, a small molecule inhibitor of Ras-related $\mathrm{C} 3$ botulinum toxin substrate 1 (Rac1), attenuates glucose-stimulated insulin secretion in pancreatic beta-cells. Cell. Signal., 27, 1159-1167 (2015).

7) Jayaram B, Syed I, Kyathanahalli CN, Rhodes CJ, Kowluru A. Arf nucleotide binding site opener [ARNO] promotes sequential activation of Arf6, Cdc42 and Racl and insulin secretion in INS 832/13 beta-cells and rat islets. Biochem. Pharmacol., 81, 1016-1027 (2011).

8) Veluthakal R, Madathilparambil SV, McDonald P, Olson LK, Kowluru A. Regulatory roles for Tiam1, a guanine nucleotide exchange factor for Racl, in glucose-stimulated insulin secretion in pancreatic beta-cells. Biochem. Pharmacol., 77, 101-113 (2009).

9) Chiba Y, Danno S, Suto R, Suto W, Yamane Y, Hanazaki M, Katayama H, Sakai H. Intranasal administration of recombinant progranulin inhibits bronchial smooth muscle hyperresponsiveness in mouse allergic asthma. Am. J. Physiol. Lung Cell. Mol. Physiol., 314, L215-L223 (2018).

10) Gao Y, Dickerson JB, Guo F, Zheng J, Zheng Y. Rational design and characterization of a Rac GTPase-specific small molecule inhibitor. Proc. Natl. Acad. Sci. U.S.A., 101, 7618-7623 (2004).

11) Shutes A, Onesto C, Picard V, Leblond B, Schweighoffer F, Der CJ. Specificity and mechanism of action of EHT 1864, a novel small molecule inhibitor of Rac family small GTPases. J. Biol. Chem., 282, 35666-35678 (2007).

12) Barnes PJ. Muscarinic receptor subtypes in airways. Life Sci., 52 , 521-527 (1993).

13) Haddad EB, Landry Y, Gies JP. Muscarinic receptor subtypes in guinea pig airways. Am. J. Physiol., 261, L327-L333 (1991). 